\title{
Law and Order and the American Criminal Justice System
}

\author{
By David L. Sutton, Melissa Britts, Margaret Landman
}

Fall 2000 Issue of KINEMA

\section{TELEVISION PROGRAMMES AS LEGAL TEXTS: WHAT LAW AND ORDER TELLS US ABOUT THE AMERICAN CRIMINAL JUSTICE SYSTEM}

In this work, we take the perspective that although a television program is produced for the brief amusement of a mass audience, it can be viewed as having a part in the scholarly investigation of law and justice in our society. The central question we are focussing on is: What does Law \& Order programme tell its audience about the American criminal justice system?

According to one of the program's official web sites, Law $\mathcal{E}$ Order is a "realistic" television series that examines "law and order from a dual perspective." For roughly the first half-hour, the program focuses on two New York Police Department (NYPD) detectives as they "investigate crimes and apprehend law-breakers." Then the scene switches to the criminal courts, where two assistant district attorneys "work within a complicated justice system to prosecute the criminals." (1)

We take the position that a television program can be examined as a legal text. John Denvir posits that films can be studied as legal texts because they share a common feature with the "normal legal trilogy of constitutions, codes, and cases." Like this group of texts, films are also "cultural artifacts open to warring interpretations both on the descriptive and normative level." ${ }^{(2)}$ We posit that one can easily make the same point about television programs, another prevalent cultural artifact of our current times. Although a television program is produced for the entertainment of a mass audience, we would argue that it too can be viewed as having a part in the investigation of law and justice in our society. In our analysis we seek to answer one question: What does the television series Law $\&$ Order tell its audience about the American criminal justice system?

Methodology

In The Philosophy of Literary Form, Kenneth Burke posits that "the focus of critical analysis must be upon the structure of a given work itself. Unless this requirement is fulfilled, and amply, the critic has slighted [his/her] primary obligation." (3) The first step in analysing a text, Burke states, is to develop a set of equations "by tracing down the interrelationships as revealed by the objective structure of the [text] itself." (4) Using these equations allows the critic to "collapse into a single chord a series of events that, by the nature of the literary medium, must be strung out in arpeggio." (5) This type of analysis allows the critic to sketch out relationships and hierarchies that are played out within the drama.

Burke suggests that the two main mathematical symbols a critic should use in mapping out a text's structural relationships are the equal sign $(=)$ and the arrow $(->)$. Although he leaves the exact meaning and usage of these symbols to the judgment of the individual critic, Burke offers an example of how he might employ them. For example, when presented with the line "the sunny mist, the luminous gloom of Plato," a critic may at first view the relationship among the three images as metaphoric in nature. So the critic diagrams this relationship with the initial equation of "sunny mist = luminous gloom = Plato." However, after further examination of the entire text, the critic may view this relationship as somewhat more progressive in nature, as in one thing leads to another. The critic could then revise the equation to read "sunny mist->luminous gloom->Plato"(6) In this way Burke suggests that the relationships are more than mere metaphors but exist as a rhetorical argument that invites the reader to arrive at a conclusion about the relationships. This type of progressive argument is common in the juxtapositions of images in cinematic dramas. The audience is invited to compare and contrast often diverse images so that they will make cognitive and often ideological assumptions about the relationships. Moreover, these relationships can suggest attitudes, beliefs, and values that offer support or challenges to existing cultural and societal positions, hierarchies, and ideologies. Therefore, the use of these rather simple equations can prove to be very useful in outlining and suggesting how a particular text's dramatization situates itself in relationship to hegemonic discourses. 
In this paper, we will follow Burke's proposed methodology and focus our attention on the structure of several episodes from the ninth season (1998-1999) of the television series Law $\&$ Order. ${ }^{(7)}$ We will use mathematical symbols to map out the relationships found within them. This quasi-mathematical methodology has been used before in the analysis of a television news program. ${ }^{(8)}$ We hope to further extend the understanding of Burke's proposed methodology by applying it to a television drama series.

\section{Analysis and Discussion \\ Equation 1: Law \& Order = The Detective Story \\ + The Trial Narrative}

The first equation that is readily apparent to the program's audience is the combination of two traditional genres of Western literature: the detective story and the trial narrative. Although one might be tempted to dismiss this observation as patently obvious, McConnell argues that such a pairing was a very astute move on the part of the program's creator, Dick Wolf. Frank McConnell notes that the detective story and the trial narrative "are not only complementary, but mutually exclusive." The traditional detective story ends when the chief investigator--e.g., Sherlock Holmes, Nero Wolfe, Hercule Poirot, or Brother Cadfael-gathers enough clues to reconstruct the scene of the crime and uncover the identity of the perpetrator. Once confronted with the evidence against him/her, the "perp" has no choice but to confess and surrender to the authorities. In the traditional detective story, this person is so obviously guilty that conducting a trial would be pointless. ${ }^{(9)}$

The classic trial narrative, such as the Perry Mason stories, follows two basic scenarios. In both scenarios the defendant presents himself/herself as wrongfully accused. In the first scenario, the heroic defence counsel uses an encyclopaedic knowledge of the law and an absolute command of the facts to cross-examine each witness, slowly chipping away at the prosecution's seemingly ironclad case. Finally, the psychological tension in the courtroom is so great that a key prosecution witness breaks down on the stand and tearfully confesses that he/she, and not the defendant, actually committed the crime. The second is the "surprise witness" scenario. Through persistent investigation, the heroic defence counsel uncovers a witness that the police and prosecutors have overlooked. Always introduced by defence counsel at the last possible moment, and over the vociferous objections of the prosecution, the surprise witness presents testimony which points the finger of guilt away from the defendant and toward the real criminal.

In addition to combining these two heretofore mutually exclusive genres, the creators of Law and Order have re-invented the crime drama recipe. According to McConnell, Law \& Order tells its story with a "deliberate and bracing coldness." Crime drama has traditionally been melodrama. Mixed in with the crime scene evidence are aspects of the main characters' personal lives. Not only do we in the audience care about solving the crime, but along the way we're supposed to develop a liking for the main characters-e.g., Columbo, Horace Rumpole, or Inspector Morse. Law $\&$ Order differs from other crime dramas in that it reveals very little about the personal lives of its main characters. This detached way of storytelling has allowed the show to undergo a complete cast change since its pilot episode with no apparent adverse effect on its ratings. ${ }^{(10)}$

\section{Equation 2: The Detective Story $=$ Discovery of a Crime-- $>$ Investigation of the Crime-- $>$ Discovery of Key Piece of Physical Evidence-->Arrest of the Suspect}

As mentioned earlier, approximately the first half of Law $\& 3$ Order is a detective story. As the above equation indicates, this part of the program follows a four-segment formula. In the first segment someone discovers a crime. Unlike other crime dramas, Law \& Order rarely shows its audience a crime being committed. An ordinary citizen involved in his/her everyday routine stumbles across the gruesome remnants of some horrible deed, usually in the form of a bloody corpse. An abrupt fade to black follows and immediately detectives Lennie Briscoe and Reynaldo "Rey" Curtis arrive on the scene to begin gathering details about the crime. This opening segment is extraordinarily brief, confined to less than two minutes.

The bulk of the detective story is taken up with the second and third segments. In the second segment the audience accompanies the detectives as they "hit the streets" to investigate the crime. The detectives travel to various locations throughout the city as they interview witnesses and consult with assorted lab technicians. The transition into the third segment is a subtle one. Gradually the focus of their investigation narrows to one suspect. Through methodical police work and astute interrogation techniques, Briscoe and Curtis 
uncover a key piece of physical evidence that unquestionably links the suspect to the crime. In the fourth and final segment, which is the briefest of all, Briscoe and Curtis arrest the suspect. As noted above, this final segment would normally be the end of the traditional detective story; the suspect's guilt is so obvious that a courtroom trial will be just a brief formality.

As noted in the previous section, Law $\&$ Order differs from the typical television crime drama in its detached way of presenting the main characters. Briscoe and Curtis rarely speak with each other about their private lives; thus, the audience doesn't get a complete picture of these characters. We know them as criminal investigators and little else. The program also varies from the conventional crime drama in another respect. Wolf states that his scenes run "from meat-to-meat . . . there are no transitions, no drive-ups, none of that ease of flow that a lot of people are used to." For example, there are no scenes in which Briscoe and Curtis have a friendly chat in a police car as they drive through the city to meet a witness. An inter-title with a two-note musical score announces their location, they ask someone a few questions, gather a bit of information, then leave. Back in the squad room the two detectives work their way through massive files and computer printouts at a sprightly pace, limiting their banter to sardonic one-liners. They uncover the information they need with a limited amount of paper shuffling. As a result of this abbreviated story-telling technique, Wolf states that this program presents its audience with a "heightened reality and a compressed reality." (11) On Law $\& 3$ Order the entire investigative process, from the discovery of a crime to the arrest of a prime suspect, takes less than thirty minutes.

\section{Equation 3: Det. Lennie Briscoe + Det. Rey Curis + Audience $=$ Investigative Team}

The "reality" of the Law \& Order detective story is also influenced by its cinematography, which closely approximates cinema vérité. As the above equation indicates, using this technique invites the audience to become a member of the investigative team. As Bordwell and Thompson remind us, a traditional film uses scripting, staging, editing, music, and voice-over narration to guide the audience toward a conclusion; however, a cinema vérité documentary "records an ongoing event 'as it happens,' with minimal interference by the filmmaker." (12) The use of a hand-held camera produces an unstable image and thus magnifies the perception of immediacy, "as if the action were glimpsed on the fly." (13) Portable sound equipment records ambient noise, which also gives the feeling of capturing an unrehearsed event.

Its defenders claim that cinema vérité is an objective means of recording events, more so than traditional documentary films. Bordwell and Thompson point out, however, that cinema-vérité filmmakers make numerous decisions which can influence an audience. The cinema-vérité filmmaker first decides what subject matter will be filmed. He/she also makes instantaneous decisions while filming, such as when to start and stop the camera, from what angles to film his/her subjects, what material to keep in frame, and what sounds to record. During the editing process, the filmmaker chooses and organizes the recorded images and sounds into a final order. Bordwell and Thompson conclude: "Through selection and arrangement, the cinema-vérité filmmaker utilizes film form and style no less than does a filmmaker who employs mise-en-scene and stages the action for the camera." ${ }^{\prime 14)}$

Law $\mathscr{E}$ Order is a prime-time television drama, so its plot and dialogue are obviously scripted. By borrowing from the techniques of cinema vérité, however, the producers of Law $\mathscr{E}$ Order give us in the audience the perception that we are witnessing a realistic criminal investigation. In essence, we each become a third investigator. We follow Briscoe and Curtis as the two detectives interview witnesses, receive briefings from lab technicians, search various locations for physical evidence, and interrogate suspects. When Briscoe and Curtis finally make an arrest, there should be little doubt in our minds regarding the suspect's guilt because, as a third investigator, we have heard and seen all of the evidence. We have been drawn into the detective story by an illusion of participation in solving the crime. We believe that we have arrived at an independent conclusion, but it is a conclusion that was scripted for us long before the actors uttered their first lines.

\section{Equation 4: Lt. Van Buren = Det. Lennie Briscoe $=$ Det. Rey Curtis}

This next equation illustrates the egalitarian working relationship between the two detectives and their immediate supervisor Lieutenant Anita Van Buren. One can observe a definite team-work approach in the Law \& Order squad room. Van Buren's role is more of a facilitator than a commanding officer. She 
gives direction to the investigation by asking probing questions and by offering discerning observations and suggestions.

Conflict is the foundation for all drama. ${ }^{(15)}$ As would be expected in a drama series, interpersonal differences surface between the Law $\&$ Order detectives, and yet they do not engage in testosterone-induced shouting matches with each other or with Van Buren. If Law $\&$ Order were a traditional hour-long television drama, then resolving a conflict between characters would be a sub-plot of the main story line. The detectives would work on solving the crime at the same time as they work through their interpersonal differences. As we have seen in an earlier part of this paper, Law $\&$ Order operates in a condensed reality; the crime must be solved and a suspect must be arrested in less than a half hour.

The writers overcome this time constraint by limiting the conflicts the Law $\&$ Order detectives can have to a specific low-intensity type. John Keltner prefers to substitute the term "struggle" for "conflict" and defines it as follows: "Struggle is an act of striving against some form of resistance or opposition. . . . Struggle is the basic experience that underlies all the forms of tension humans experience from mild disagreement to violence." (16) Keltner places human struggles along a spectrum from lowest to highest intensity: mild difference, disagreement, dispute, campaign, litigation, fight or war. ${ }^{(17)}$ The struggle spectrum, Keltner posits, is grounded in an inherent pattern we humans follow as we attempt to settle our differences. Fights and wars are not spontaneous occurrences; rather, they unfold through a process of incremental stages. Unless this process is somehow disrupted, interpersonal tensions escalate from the innocuous to more extensive instances of struggle ending in violence. ${ }^{(18)}$

The Law 8 Order detectives are confined to the first stages on Keltner's struggle spectrum, i.e., mild difference. In this first stage of struggle, according to Keltner, people experience "a relatively limited collision of interests." A change in status quo, conflicting time commitments, varying goals, changes in practice, and different preferences can be the sources of this collision. ${ }^{(19)}$ These mild differences arise at some point between the Law $\&$ Order detectives on two levels. On a personal level these differences are understandable because of their varying cultural and ethnic backgrounds, e.g., opinions on abortion, affirmative action, et cetera. On a professional level, the detectives sometimes arrive at different interpretations of the evidence they uncover in the process of their investigation.

The behaviour manifested at this first stage is "a joint problem solving activity where the parties, in a friendly and collaborative manner, explore the problem and reach decisions together."(20) People at this level have mutually inclusive goals and are oriented to be cooperative and congenial towards one another. Their communication is remarkably free of obstructions, i.e., "there are no blocks or interferences that prevent them from saying what they think and feel to each other, and each respects the other's differing point of view." Decisions are reached by consensus with all parties satisfied with the outcome. ${ }^{(21)}$ In watching Law E Order, one can clearly see that Briscoe and Curtis are a well-synchronized investigative team. There is no competition between them to see who can be the "top cop." There is no contest to accumulate "brownie points" with Van Buren or the district attorneys. They readily offer and accept suggestions from their partner and from Van Buren. When one detective's approach doesn't produce results, the other detective easily steps in to try a different tactic, especially during interrogation scenes. When an arrest is made, they both get credit for "the collar." Other precincts may be rife with conflict, but in the Law $\&$ Order squad room the detectives' personal and professional differences are minor and quickly resolved. These differences do not serve as a roadblock but as a catalyst driving their investigation forward.

Referring back to our original research question, what does the Law $\&$ Order detective story tell its audience about the American criminal justice system? Of the four equations generated in our analysis of the Law 83 Order detective story, we posit that Equation 2 governs this part of the program. Plainly, this equation asserts that there is a clear trail of evidence that leads inexorably from the crime scene to a suspect, i.e., 'all crimes have a solution.'

Law enforcement agencies consider a crime cleared or solved "when at least one person is arrested, charged with the commission of the offense, and turned over to the court for prosecution." For the year 1997, according to statistics published by the US Department of Justice, only 66 percent of all homicides committed in the United States were cleared. In 1976, that figure stood at 79 percent. ${ }^{(22)}$ In reality, some people do indeed get away with murder. This paper, however, is not about reality but about network television. Common 
sense would dictate that Law $\&$ Order's two-part formula (see Equation 1) wouldn't work if only 69 percent of the crimes ended in an arrest; the trial narrative needs someone to play the part of the accused. With a suspect arrested, our attention now shifts to the second portion of Law \& Order, the trial narrative.

\section{Equation 5: The Trial Narrative = Continued \\ Investigation-- $>$ Struggle to Overcome a Legal Barrier-->Trial/Plea Bargain Conference-->Epilogue}

As mentioned above, the second portion of Law $\&$ Order is the trial narrative. As the above equation indicates, this part of the program follows a four-segment formula. In the first segment, the assistant district attorneys (ADAs) have taken over the case from the detectives. Although detectives Briscoe and Curtis have gathered enough evidence to arrest a suspect, most of the time Executive ADA Jack McCoy and ADA Abbie Carmichael must continue the investigation in order to gather the additional evidence needed to take the case to trial.

In the second segment of the formula, McCoy and Carmichael encounter a legal barrier and must find some way to overcome it. Usually the defendant's attorney has introduced a motion seeking to block the admission of the key piece of evidence that was uncovered in the first half of the program. If a judge rules that the key piece of evidence is inadmissible, the ADAs' case becomes severely weakened.

The third segment contains two possible paths for the ADAs to take. If the barrier is not overcome, then McCoy and Carmichael must continue their investigation until they uncover a different piece of evidence to use. If the barrier is overcome, then the ADAs move their case to trial. Sometimes the evidence is so overwhelming that McCoy and Carmichael have a plea bargain conference with the defendant and his/her lawyer. They lay out their case and negotiate a plea of guilty from the defendant, who by this time is willing to accept their offer in order to avoid a lengthy prison sentence.

The fourth and final segment is the epilogue, and it is the briefest of all the segments. The ADAs and their boss, District Attorney Adam Schiff, gather in someone's office or by the elevators or on the courthouse steps to exchange a pithy "last word" about some key issue or aspect of their case.

As with the detective story portion of Law $\&$ Order, the trial narrative also operates in a compressed reality. In keeping with the detached storytelling technique of the program, we in the audience know very little about the personal lives of the ADAs. Family members, friends, and lovers may be mentioned in a line of dialogue, but they exist in a world that is off-camera and seldom visited. We in the audience are privy to their intra-office conferences at which the ADAs discuss trial tactics and legal issues, but rarely anything about who they are or what they do after working hours. Outside of the office the ADAs may talk over a meal in a restaurant or drinks in a bar, but the main topic of discussion is their case. A personal detail pops up in a conversation only if it directly relates to their case and thus serves to advance the storyline. There are no transition scenes here either. An inter-title with a two-note musical score announces the location of the ADAs, whether they are in the field gathering additional information or in a courtroom trying their case. On Law $\&$ Order trials move along at a remarkably brisk pace; the New York criminal court system functions at the peak of efficiency, and all of the lawyers, both prosecutors and defence attorneys, exhibit consummate trial skills. James Wolcott juxtaposes Law \& Order against CourtTV and observes: "Where actors portraying lawyers stiffen their necks as if being fitted for halos, the real-life lawyers . . . plod through their notes, losing their place as their glasses slide down their noses. . . . At CourtTV's slowest, the camera seems to be collecting lint." (23) On Law $\mathcal{G}$ Order, a criminal suspect is arraigned, tried, convicted, sentenced, or plea-bargained in less than thirty minutes.

\section{Equation 6: Assistant District Attorneys > Detectives}

Unlike the egalitarian working relationship we found among the detectives in the first half of the program, a definite hierarchy exists in the second half of Law $\&$ Order. In this portion of the show, the detectives work under the direction of the ADAs, not alongside them. Van Buren, Briscoe, and Curtis may consider the evidence they have against a suspect to be "rock solid," but all their work can be dismissed with one comment from an ADA, "Sorry, guys, it's not enough to take to court." In the Law $\mathcal{G}$ Order detective story there is no dominant character; we observe the interactions of a team of investigators. In the trial narrative portion of the program, Executive ADA Jack McCoy becomes the focus of the audience's attention. His pursuit of justice is the core of the trial narrative. The following equations demonstrate that McCoy unquestionably 
sits atop the Law $\&$ Order hierarchy.

\section{Equation 7: McCoy > Audience}

As we noted earlier, the producers construct the reality of the Law $\&$ Order detective story by borrowing from the techniques of cinema vérité. This technique draws the audience into the action of the story, making them a third investigator. In the Law $\&$ Order trial narrative, the producers rely on a more traditional cinematography that gives this part of the program a more polished look. The result is to push the audience out of the story, making them assume the stance of an observer and not a participant. Our common sense experience lends us some expertise in being an criminal investigator; however, for most of us in the audience the New York state criminal code and case law falls outside of our area of expertise. We may listen as McCoy talks to Carmichael and about trial strategy, but we are limited in our participation to that of observers. In essence our role as an audience member has changed from investigator to juror; we must rely on the attorneys as experts in the law to present the case to us.

\section{Equation 8: McCoy > Defendants}

People who are charged with crimes on Law $\mathcal{E}$ Order come from all levels of society, from the most privileged down to the least fortunate. The program's writers have even tapped police officers to be perpetrators. Despite their multi-cultural backgrounds, all of the defendants share several characteristics. First, they are all obviously guilty of the crime with which they are charged. We in the audience were there as detectives Briscoe and Curtis gathered the evidence against them. Second, most of the defendants are extremely confrontational. While McCoy maintains an air of dignity and professionalism during a pretrial conference, most defendants sneer and smirk, almost daring McCoy to take them to into court. Third, most of the defendants have difficulty with the concept of veracity. Again and again, McCoy presents them with an opportunity to tell the truth, and the defendants refuse to cooperate. We in the audience saw them lie to the detectives, and we see them continue to lie and to be evasive when McCoy questions them. The Law $\&$ Order writers are following an obvious strategy; they don't want the audience to develop any kind of empathy for these characters. We in the audience are not supposed to see the accused as someone just like us, i.e., a basically good person who made a tragic mistake. To be portrayed as truly unlikeable people means that we will feel a sense of satisfaction when the accused are found guilty, or we will experience a sense of disappointment and frustration if they "beat the rap."

\section{Equation 9: McCoy > Defence Attorneys}

In his effort to bring wrongdoers to justice, McCoy is confronted by a multi-cultural array of defence counsel. Like their clients, the defence attorneys are not very likeable people. They are all obnoxious, confrontational, and sly. In fact, the defence attorneys are the ones who construct the devilish legal barriers that McCoy must strive to overcome. As with the ADAs, we in the audience know precious little about the defence attorneys as people, other than that they are working to free their reprehensible clients. We are not shown any scenes with the defence attorneys in conference with their clients or with other defence counsel. We in the audience only see their clients and their cases through the eyes of the prosecution. Things were much different in the early days of television courtroom drama. As Rapping notes, "It used to be that the little guy, falsely accused, was proven innocent by a heroic lawyer modelled after Clarence Darrow."(24) On Law \& Order, the defence attorneys are not courageous souls protecting "the little guy" against an overzealous prosecutor; instead, they are unscrupulous shysters who prevent McCoy from bringing wrongdoers to justice.

\section{Equation 10: McCoy > Judges}

In addition to the defendants and their lawyers, McCoy encounters a multi-cultural array of judges. Though they may differ in their age, gender and ethnic heritage, all of the judges on Law $\mathcal{E}$ Order mainly serve as part of the legal obstacle that McCoy must overcome. Sometimes the judges will display sound legal reasoning in their decisions, and they refuse to let McCoy "push the envelope" in their courtrooms. At other times, they are just too timid, either intellectually or politically. Quite simply, the judges frequently don't see the law as McCoy does. We in the audience are given no additional information about the judges as people. Again, as it is with the defendants and their lawyers, we only see the judges and their decisions through the eyes of the district attorney.

Equation 11: McCoy > District Attorney Adam Schiff

At various times District Attorney Adam Schiff plays the archetypal distinguished law professor, one who 
gruffly quizzes McCoy on the legal merits of a case and who dispenses a common-sense wisdom on trial strategy. At these times, McCoy's respect for Schiff is apparent, and he defers to Schiff's experience and insight. Yet there are other times when Schiff is too timid for McCoy. In order to win particularly difficult cases, McCoy wants to break new legal ground. At these critical times, Schiff switches to the role of beleaguered politician, one who openly worries about receiving angry telephone calls from the mayor or negative coverage in the press. At these moments, Schiff becomes another obstacle that McCoy must work to overcome.

\section{Equation 12: McCoy > ADA Abbie Carmichael}

The character of Abbie Carmichael is prototypical of the ADAs who have worked with McCoy. They have all been young, female, tall, svelte, with fashion-model facial features and straight dark hair. Like her predecessors, Carmichael is an intelligent and capable attorney in her own right. Before coming to work for McCoy, she had a successful career as a prosecutor with the NYPD narcotics unit. In the Law 83 Order detective squad room, Briscoe may have seniority but he and Curtis work as a team. In the Law 8 Order district attorney's office, one can clearly see that Carmichael is the junior partner. She does most of the "grunt work" in that office, e.g., researching case law, filing motions, conducting arraignments, and interviewing witnesses. In the episodes we analysed for this paper, Carmichael rarely presented a case before a judge and jury. In most of the episodes, she sat quietly at the prosecutor's table and reacted nonverbally to the situation. The courtroom is McCoy's domain, and Carmichael serves mainly in the role of stage prop.

Outside of the courtroom, Carmichael's main task is to raise ethical concerns about McCoy's trial tactics. In one episode, for example, she learned that the detectives told a witness which suspect to identify in a line-up. McCoy later used that identification as leverage to pressure the suspect into giving testimony against his co-defendants. After the jury returned a guilty verdict, along with a recommendation for the death penalty, Carmichael voiced her concerns about the detectives' action. McCoy lightly brushed her concerns aside by saying, "I know. I told them to. Perfectly legal. We were never going to use the identification at trial anyway. . . Major felonies, Abbie. Welcome to The Bigs."

What then does the Law $\&$ Order trial narrative tell its audience about the American criminal justice system? In examining the equations that govern this portion of the program, we find that Equation 6 through Equation 12 appear as those which dominate the second half of the show. One could formulate an argument grounded in Critical Race Theory and posit that audiences are attracted to Law \& Order because this show plays to the inherent racism in American culture. ${ }^{25)}$ The central character in the trial narrative, Executive ADA Jack McCoy, is a white male. He is clearly in command, both in the office and in the courtroom. Though we are surrounded by lawlessness, we can all rest easy because a white male is still in charge. Given that Law $\&$ Order has experienced a complete casting change since the pilot episode, we suppose that such an argument could be made if the producers fail to place an African-American actor in the lead role before the show's final episode.

In the course of our analysis of the trial narrative, we found the relationship depicted by Equation 8 and Equation 9 to be genuinely intriguing. For us, these equations intimate that in the American criminal justice system the presumption of innocence is a defunct concept. According to Corpus Juris Secundum, "One who is accused is presumed to be innocent of the crime charged against [him/her]. The presumption of innocence exists in every criminal case and extends to every person and corporation accused of any crime, and it applies to every element of the crime charged." (26) Having been privy to the criminal investigation, the Law $\&$ Order television audience has seen the much of the evidence against the accused; therefore, that person's guilt is a foregone conclusion. In the Law $\mathcal{B}$ Order courtroom, the trial narrative is all about the honourable prosecution team struggling mightily against scheming defence attorneys and their nefarious clients. In reality, according to an investigation conducted by the Pittsburgh Post-Gazette, even prosecutors engage in unethical conduct in order to win. ${ }^{(27)}$

\section{Conclusion}

To say that Law $\mathcal{E}$ Order is highly formulaic may seem like stating the patently obvious. However, being highly formulaic has contributed greatly to the show's commercial success. From a rhetorical perspective, we must continue to ask whether audiences attracted to this program because of its realistic portrayal of events or because of its reassuring images. 


\section{Notes}

1. NBC. "Law \& Order." 1998. (25 January 1999).

2. John Denvir, ed., Legal Reelism: Movies as Legal Texts (Urbana, IL: U of Illinois Press, 1996) xii.

3. Kenneth Burke, The Philosophy of Literary Form (Berkeley: U of California Press. 1941/1973) 73.

4. Burke 70 .

5. Burke 75. 6. Burke 75 .

7. The episodes appear in the order of their broadcast date: "Cherished" (23 Sept. 1998), "DWB" (7 Oct. 1998), "Agony" (4 Nov. 1998), "Scrambled" (11 Nov. 1998), "Venom" (18 Nov. 1998), "Hate" (6 Jan. 1999), "Ramparts" (13 Jan. 1999), "Haven" (20 Jan. 1999), "Hunters" (27 Jan. 1999), "Disciple" (24 Feb. 1999), "Harm" (3 March 1999), "Shield" (24 March 1999), and "Empire," the series' 200th episode (5 May 1999).

8. David L. Sutton, "Schwarzkopf in 'Nam," Kinema 10 (1998): 19-30.

9. Frank McConnell, "Law and order," rev. of Law \& Order, Commonweal 4 Nov.1994: 19, online, Infotrac Search Bank, Expanded Academic ASAP, article no. A15892213.

10. Bill Carter, "Tracking Down Viewers Till They're Captured," The New York Times 14 Feb. 1997: C11+. 11. Arthur Unger, "It's the Writing, Stupid!" Television Quarterly 28.2 (1997): 10-23.

12. David Bordwell and Kristin Thomas, Film Art: An Introduction, 5th ed. (New York: McGraw-Hill, 1997) 44.

13. Bordwell and Thomas 246 .

14. Bordwell and Thomas 410.

15. Syd Field, Screenplay: The Foundations of Screenwriting (New York: Dell, 1972).

16. John Keltner, "From Mild Disagreement to War: The Struggle Spectrum," Bridges Not Walls, ed. J. Stewart (New York: McGraw-Hill, 1990) 320.

17. Keltner 321. 18. Keltner 319. 19. Keltner 322. 20. Keltner 323. 21. Keltner 323.

22. United States Department of Justice Bureau of Justice Statistics. "Homicide trends in the U.S.: Clearance." 1999. (22 July 1999).

23. James Wolcott, "Prime-Time Justice," The New Yorker 30 November 1992: 159.

24. Elayne Rapping, "Land of good-guy prosecutors," The Progessive May 1996: 38.

25. Kimberle Crenshaw, Neil Gotanda, Gary Peller, and Kendall Thomas, eds., Critical Race Theory: The Key Writings that Formed the Movement (New York: The New Press, 1995).

26. 22A C.J.S. 337.

27. Bill Moushey, "Win at all costs: Government misconduct in the name of expedient justice," Pittsburgh Post-Gazette (22 Nov. 1998 through 13 Dec. 1998), online, Internet, 27 Mar. 1999. 